\title{
Kreativitas Peserta Didik Mengikuti Bimbingan Konseling dengan Menerapkan Contoh Prilaku yang Baik
}

\author{
I Wayan Murdana*
}

SMPN 3 Denpasar, Indonesia

\begin{abstract}
Abstrak
Penelitian tindakan kelas yang dilaksanakan dilatar belakangi oleh rendahnya kreativitas peserta didik dalam mengikuti bimbingan konseling dengan menerapkan contoh prilaku yang baik di kelas IXB semester I SMP Negeri 3 Denpasar Keywords:

Contoh-Contoh Prilaku yang Baik, Kreativitas, Bimbingan Konseling. tahun pelajaran 2018/2019 yang baru mencapai 62,45 dengan kriteria kurang. Tujuan tersebut lebih jelas lagi dan lebih terfokus lagi adalah untuk meningkatkan kreativitas peserta didik dalam mengikuti bimbingan konseling dengan menerapkan contoh prilaku yang baik di kelas IXB semester I SMP Negeri 3 Denpasar tahun pelajaran 2018/2019. Peningkatan kreativitas tersebut datanya diperoleh lewat observasi, selanjutnya dianalisis menggunakan analisis deskriptif. Perolehan data hasil penelitian ini, ternyata menggembirakan setelah cara pembelajaran yang konvensional dirubah menggunakan pemberian contoh prilaku yang baik. Kegiatan penelitian ini menghasilkan suatu peningkatan yang diharapkan yaitu meningkatnya rata-rata kreativitas awal yang baru mencapai 62,45 dengan kriteria kurang, pada siklus I rata-rata kreativitas naik menjadi 71,43 dengan kriteria cukup dan pada siklus II rata-rata kreativitas naik menjadi 80,73 dengan kriteria baik. Hasil tersebut membuktikan keberhasilan penelitian ini sehingga peneliti berkesimpulan bahwa kreativitas peserta didik dapat meningkat dalam mengikuti bimbingan konseling dengan menerapkan contoh prilaku yang baik di kelas IXB semester I SMP Negeri 3 Denpasar tahun pelajaran 2018/2019.
\end{abstract}

\section{PENDAHULUAN}

sistem pendidikan di Indonesia dewasa ini tampak ada kesenjangan antara kenginan dan realita. Secara makro dapat dilihat dalam aspek pengelolaan, peran pemerintah dan masyarakat, kurikulum atau materi ajar, pendekatan dan metodologi pembelajaran, sumber daya manusia, lingkungan kampus atau sekolah, dana, dan akreditasi. Kesenjangan dalam sistem pendidikan tersebut disebabkan karena faktor politik, ekonomi, sosial-budaya dan sebagainya yang selalu berubah sesuai dengan perubahan dan perkembangan zaman (Murniah, 20115). Menurut Afrianto (2011) Kebutuhan pendidikan merupakan salah satu bagian terpenting dari kehidupan manusia, dengan pendidikan yang lebih tinggi diharapkan akan manghasilkan manusia-manusia yang lebih berkualitas. Pendidikan merupakan usaha sadar dan terencana untuk mewujudkan suasana belajar dan proses pembelajaran agar peserta didik secara aktif mengembangkan potensi dirinya untuk memiliki kekuatan spiritual keagamaaan, pengendalian diri, kepribadian, kecerdasan, akhlak mulia, serta ketrampilan yang diperlukan dirinya, masyarakat, bangsa, dan Negara. Tujuan pendidikan yaitu untuk berkembangnya potensi peserta didik agar menjadi manusia yang beriman dan bertakwa kepada Tuhan Yang Maha Esa, berakhlak mulia, sehat, berilmu, cakap, kreatif, mandiri, dan menjadi warga negara yang demokratis serta bertanggung jawab. Melihat perkembangan ilmu pengetahuan dan teknologi semakin pesat, arus globalisasi semakin hebat sehingga munculnya persaingan dalam bidang kehidupan, di antaranya bidang pendidikan, maka untuk menghadapi

* Corresponding author.

E-mail Addresses: - murdanaiwy@gmail.com (I Wayan Murdana) 
persaingan tersebut dibutuhkan sumber daya manusia yang berkualitas, salah satu cara yang ditempuh adalah peningkatan mutu pendidikan melalui bimbingan dan konseling terhadap kreativitas.

Kreativitas adalah hasil dari interaksi antara individu dan lingkungannya seseorang mempengaruhi dan dipengaruhi oleh lingkungan dimana ia berada dengan demikian baik berubah di dalam individu maupun di dalam lingkungan dapat menunjang atau dapat menghambat upaya kreatif. Guna mencapai hasil olah kreativitas yang maksimal, maka guru dituntut agar lebih tepat dalam menentukan media pengajaran.Namun hal yang tak kalah penting juga adalah dikuasai atau tidaknya materi pelajaran tersebut. Dengan kata lain sebagai guru, ternyata ada tuntutan baginya untuk berolah kreativitas secara langsung dihadapan peserta didik.

Bimbingan belajar merupakan salah satu bidang bimbingan yang sangat penting untuk diberikan kepada peserta didik karena dapat memberikan pemahaman kepada peserta didik tentang berbagai hal yang berkaitan dengan kegiatan belajar. Bimbingan belajar membantu peserta didik mengembangkan diri, sikap dan kebiasaan belajar yang baik, menguasai pengetahuan dan keterampilan serta menyiapkannya melanjutkan pendidikan yang lebih tinggi. Bimbingan belajar merupakan bimbingan dalam hal menemukan cara belajar yang tepat dalam memilih program studi yang sesuai dan dalam mengatasi kesukaran-kesukaran yang timbul berkaitan dengan tuntutan-tuntutan belajar di suatu institusi pendidikan.

Berdasarkan kondisi yang terjadi di SMP Negeri 3 Denpasar peneliti sebagai guru bimbingan konseling di kelas IXB Semester I SMP Negeri 3 Denpasar Tahun Pelajaran 2018/2019, menemukan bahwa peserta didik belum sepenuhnya memiliki kreativitas dalam belajar. Dari hasil obeservasi di kelas Kelas IXB Semester I SMP Negeri 3 Denpasar Tahun Pelajaran 2018/2019 dapat disampaikan data diantaranya peserta didik sering merasa malas belajar, peserta didik tidak dapat menerapkan cara belajar yang baik, minat baca peserta didik rendah, peserta didik sulit mengerti isi buku pelajaran yang dibaca, sehingga mereka kurang memiliki usaha belajar, tidak memiliki kebiasaan belajar yang baik, dan masih terpaku dengan semua materi yang tertera di dalam buku tidak dengan mempelajari materi inti atau membuat ringkasan materi. Hal tersebut didukung dengan informasi yang diberikan oleh guru mata pelajaran bahwa ketika pelajaran peserta didik cenderung pasif atau berbicara dengan temannya dari pada bertanya atau menanggapi penjelasan dari guru. Menyikapi gejala tersebut di atas, maka penulis melakukan penelitian dengan judul "Meningkatkan Kreativitas Peserta Didik Dalam Mengikuti Bimbingan Konseling Dengan Menerapkan Contoh Prilaku Yang Baik Di Kelas IXB Semester I SMP Negeri 3 Denpasar Tahun Pelajaran 2018/2019".

Pada penelitian ini, rumusan masalah yang diajukan peneliti adalah apakah kreativitas peserta didik dapat meningkat dalam mengikuti bimbingan konseling dengan menerapkan contoh prilaku yang baik di dikelas IXB Semester I SMP Negeri 3 Denpasar Tahun Pelajaran 2018/2019?

Tujuan Penelitian ini adalah meningkatkan kreativitas peserta didik dalam mengikuti bimbingan konseling dengan menerapkan contoh prilaku yang baik di dikelas IXB Semester I SMP Negeri 3 Denpasar Tahun Pelajaran 2018/2019.

Hasil penelitian ini diharapkan akan bermanfaat bagi : bagi guru-guru bimbingan konseling, hasil penelitian ini diharapkan dapat dijadikan acuan dalam menyusun strategi pembelajaran untuk dapat meningkatkan kreativitas peserta didik. Bagi sekolah khususnya SMP Negeri 3 Denpasar, hasil penelitian ini dapat meningkatkan kualitas pendidikan di sekolah, dapat digunakan sebagai bahan kajian dalam upaya peningkatan mutu, dapat dijadikan bahan kajian dalam pembelajaran yang berhubungan dengan bimbingan konseling. Bagi peserta didik, dapat meningkatkan keterampilan berpikir sebagai bekal bagi mereka untuk dapat memecahkan masalah-masalah dalam kehidupan mereka. Bagi pengawas sekolah, hasil penelitian ini akan sangat bermanfaat sebagai pegangan dalam membina guru-guru di sekolah.

Menurut Boty (2018) Kreativitas merupakan kemampuan seseorang untuk menciptakan, memadukan pemikiran dan imajinasi sehingga menghasilkan sesuatu yang bersifat original baik berupa ide-ide, kegiatan dan performa unik yang dapat menarik minat banyak orang atau sebagai kemampuan untuk memberikan gagasan baru dalam upaya pemecahan masalah. Menurut Suhaya (2016) Kreativitas adalah kemampuan sesorang untuk menghasilkan komposisi, produk atau gagasan apa saja yang pada dasarnya baru, dan sebelumnya tidak ada yang membuatnya. Ia dapat berupa kegiatan imajinatif atau sintesis pemikiran yang hasilnya bukan hanya perangkuman, tetapi mencakup pembentukan pola baru dan gabungan informasi yang diperoleh dari pengalaman sebelumnya dan pencangkokan hubungan lama ke situasi baru dan mungkin mencakup pembentukan korelasi baru. Menurut Yahya (2013) Secara operasional kreativitas dapat dirumuskan sebagai kemampuan yang mencerminkan kelancaran, keluwesan (fleksibilitas), dan orisinalitas dalam berpikir, serta kemampuan untuk mengelaborasi (mengembangkan, memperkaya, dan memerinci) suatu gagasan. Kemampuan memberikan penilaian atau evaluasi terhadap suatu objek atau situasi juga mencerminkan kreativitas, jika dalam penilaiannya seseorang mampu melihat objek, situasi, atau masalahnya dari sudut pandang yang berbeda-beda. 
Misalnya anak diberi gambar atau uraian mengenai suatu objek atau keadaan dan ia diminta mengatakan apa saja yang kurang atau tidak cocok pada gambar atau uraian tersebut.

Menurut Munandar (2009:25) kreativitas sebagai kemampuan untuk menciptakan sesuatu yang baru, sebagai kemampuan untuk memberi gagasan baru yang dapat diterapkan dalam pemecahan masalah, atau sebagai kemampuan untuk melihat hubungan baru antara unsur yang sudah ada sebelumnya. Kreativitas seseorang dapat dilihat dari tingkah laku atau kegiatannya yang kreatif. Menurut Slameto (2003:146) bahwa yang penting dalam kreativitas bukanlah penemuan sesuatu yang belum pernah diketahui orang sebelumnya, melainkan bahwa produk kreativitas merupakan sesuatu yang baru bagi diri sendiri dan tidak harus merupakan sesuatu yang baru bagi orang lain atau dunia pada umumnya. Manusia kreatif adalah orang yang mampu berpikir kreatif. Orang dikatakan mampu berpikir kreatif jika ia mampu menemukan ide dan gagasan baru atas pengetahuan yang lama, dan juga mampu mengembangkan pengetahuan yang sudah ada.

Berdasarkan definisi di atas, maka menyimpulkan bahwa kreativitas adalah potensi daya kreatif yang dimiliki individu sebagai bentuk pemikiran dalam menemukan hubungan antara unsur yang sudah ada atau cara baru dalam menghadapi masalah yang datang dari diri sendiri berupa hasrat dan motivasi yang kuat untuk berkreasi.

Ciri-ciri kreativitas dalam dua kategori, yaitu kognitif dan nonkognitif. Ciri-ciri kognitif di antaranya: "orisinalitas, fleksibelitas, kelancaran, dan elaborasi. Sedangkan ciri-ciri nonkognitif dianataranya motivasi sikap dan kepribadian kreatif". Berdasarkan kutipan di atas dapat simpulkan bahwa kreativitas anak terlihat dari kelancaran anak dalam berfikir serta kemampuan dalam menemukan keragaman dalam mengemukakan pendapat, sehingga menimbulkan keaslian dalam berfikir dan mampu untuk menguraikan fikiran tersebut. Berdasarkan keempat ciri-ciri kreativitas di atas dapat disimpulkan bahwa anak kreatif memiliki empat ciri-ciri yang perlu dimiliki untuk menjadi kreatif, yaitu kelancaran dalam berikir, mampu berfikir luwes, dan adanya ke aslian dari fikiran, serta elaborasi dalam berfikir.

Jones (Insano, 2004:11) menyebutkan bahwa konseling merupakan suatu hubungan profesional antara seorang konselor yang terlatih dengan klien. Hubungan ini biasanya bersifat individual atau seorang-seorang, meskipun kadang-kadang melibatkan lebih dari dua orang dan dirancang untuk membantu klien memahami dan memperjelas pandangan terhadap ruang lingkup hidupnya, sehingga dapat membuat pilihan yang bermakna bagi dirinya. Bimbingan adalah proses pemberian bantuan yang dilakukan oleh orang yang ahli kepada seseorang atau beberapa orang individu, baik anak-anak, remaja, atau orang dewasa; agar orang yang dibimbing dapat mengembangkan kemampuan dirinya sendiri dan mandiri dengan memanfaatkan kekuatan individu dan sarana yang ada dan dapat dikembangkan berdasarkan norma-norma yang berlaku. Bimbingan dan konseling aitu suatu bantuan yang diberikan oleh konselor kepada konseli agar konseli mampu menyelesaikan masalah yang dihadapinya dan juga mampu mengembangkan potensi yang dimilikinya. Menurut Kamaluddin (2011) Bimbingan dan konseling merupakan upaya proaktif dan sistematik dalam memfasilitasi individu mencapai tingkat perkembangan yang optimal, pengembangan perilaku yang efektif, pengembangan lingkungan, dan peningkatan fungsi atau manfaat individu dalam lingkungannya. Semua perubahan perilaku tersebut merupakan proses perkembangan individu, yakni proses interaksi antara individu dengan lingkungan melalui interaksi yang sehat dan produktif.

Menurut Tohirin (2007), tujuan Bimbingan dan Konseling yaitu: memperoleh pemahaman yang lebih baik terhadap diri klien, mengarahkan diri klien sesuai dengan potensi yang dimilikinya, mampu memecahkan sendiri masalah yang dihadapi klien, dapat menyesuaikan diri secara lebih efektif baik terhadap dirinya sendiri maupun lingkungannya sehingga memperoleh kebahagiaan dalam hidupnya.

"Perilaku adalah segala aktivitas perbuatan, penampilan diri yang dilakukan manusia dalam kehidupannya". Anak merupakan salah satu lapisan masyarakat yang merupakan bagian dari generasi muda sebagai penerus cita-cita perjuangan bangsa dan bersumber daya manusia yang memiliki peran strategis dan mempunyai ciri dan sifat yang khusus, serta memerlukan pembinaan dan perlindungan dari orang tua maupun guru daiam rangka menjamin perhambuhan dan perkembangan fisik, mental dan, sosial serta perlindungan dari segala kemungkinan yang akan membahayakan mereka. Sejak lahir seorang anak sudah mempunyai sifat, seorang anak dapat berbuat sesuatu adalah dari Iuar dirinya, keluarga dan lingkungan dapat menjadi penentu baik buruknya tingkah laku seorang anak. Apabila seorang anak mendapt kasih sayang cukup dari orang tuanya, lingkungan serta mempunyai pendidikan ia akan dapat berbuat dan berperilaku yang baik. Bentuk-bentuk operasional dari perilaku dapat dikelompokkan dalam 3 (tiga) jenis yaitu : Perilaku dalam bentuk pengetahuan, seperti mengetahui situasi atau rangsangan dari luar. Perilaku adalah sikap, seperti batin terhadap keadaan atau rangsangan dari luar dari subjek. Perilaku dalam bentuk tindakan yang sudah konkret yang berupa tindakan terhadap situasi atau rangsangan dari luar. 
Dari pendapat di atas ternyata bahwa pembentukan perilaku itu senantiasa berlangsung dalam interaksi manusia dengan lingkungan pembentukan dipengaruhi oleh beberapa takor seperti kecerdasan, dorongan atau minat dan objek serta hasil kebudayaan yang dijadikan sasaran dalam mewujudkan bentuk perilaku. Faktor-faktor tersebut akan dapat terpadu menjadi perilaku yang terbentuk, yang dapat diterima oleh individu itu sendiri dan lingkungannya.

Hipotesis tindakan merupakan suatu tindakan yang diduga akan dapat memecahkan masalah yang ingin diatasi. Mengacu pada teori yang disampaikan, rumusan hipotesis dapat disampaikan adalah jika bimbingan konseling dibarengi dengan menerapkan contoh prilaku yang baik maka dapat meningkatkan kreativitas peserta didik kelas IXB semester I SMP Negeri 3 Denpasar tahun pelajaran 2018/2019.

\section{METODE PENELITIAN}

Pengambilan lokasi penelitian yang ditentukan adalah peserta didik di kelas IXB semester I SMP Negeri 3 Denpasar tahun pelajaran 2018/2019. Situasi sekolah yang aman adalah hal yang perlu diwujudkan. Kepala sekolah telah mengupayakannya sehingga sekolah menjadi tenang, nyaman, dan aman.

Penelitian tindakan kelas ini menggunakan rancangan dari (dalam Suharsimi Arikunto, Suhardjono, Supardi, 2007: 74). seperti terlihat pada gambar berikut.

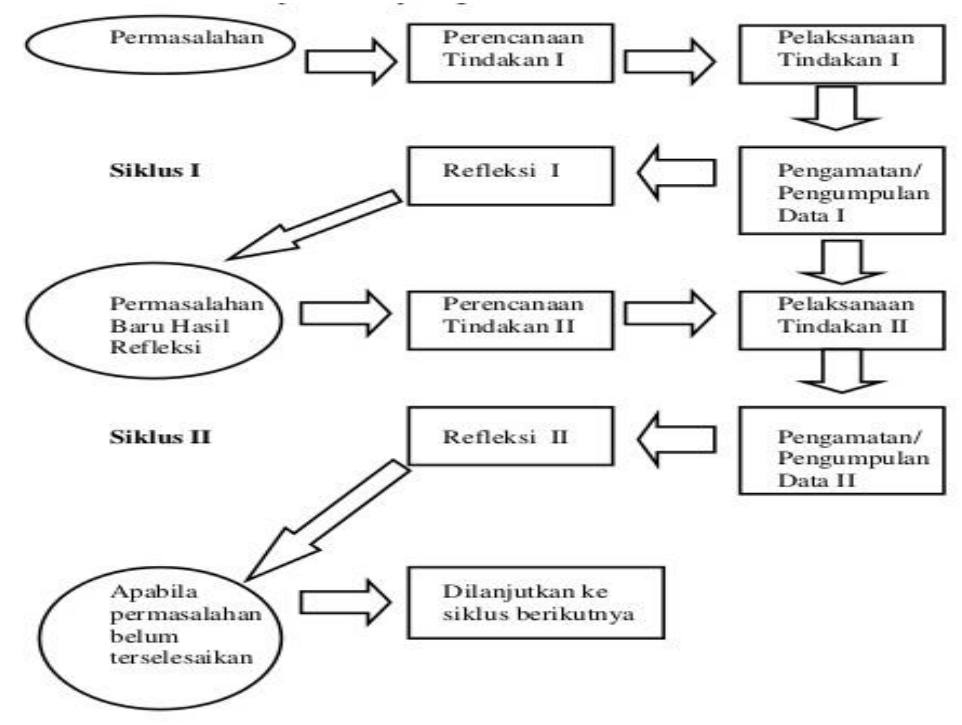

Gambar 1. Rancangan PTK (dalam Suharsimi Arikunto, Suhardjono, Supardi, 2007: 74)

Untuk mendapat data yang tepat maka perlu ditentukan informan yang memiliki kompetensi dan sesuai dengan kebutuhan data (purposive). Untuk penelitian ini, yang menjadi subjek penelitian ini adalah peserta didik pada kelas IXB semester I SMP Negeri 3 Denpasar tahun pelajaran 2018/2019.

Guru selaku peneliti menginginkan adanya perubahan kreativitas peserta didik Dalam Mengikuti Bimbingan Konseling Dengan Menerapkan Contoh Prilaku Yang Baik Di Kelas IXB Semester I SMP Negeri 3 Denpasar Tahun Pelajaran 2018/2019. Untuk mendapatkan data dalam bentuk nilai, skor atau ukuran tertentu mengharuskan peneliti untuk menentukan objek dalam penelitian ini yang berupa tindakan perlakuan yang diberikan kepada peserta didik, setelah diterapkan contoh prilaku baik.

Rencana pelaksanaan siklus untuk penelitian ini akan dilakukan sebanyak dua kali. Dalam penelitian ini, peneliti rencanakan akan berlangsung dari bulan Juli sampai bulan November 2018. Jenis data yang diperlukan dalam penelitian ini adalah data kuantitatif mengenai kreativitas peserta didik. Pengumpulan data dilakukan dengan berdasarkan observasi indikator kuisioner kreativitas peserta didik. Data-data hasil penelitian yang telah berhasil dikumpulkan menggunakan hasil observasi kreativitas peserta didik dianalisis secara deskriptif. Untuk memberikan gambaran secara jelas tentang hasil penelitian yang diperoleh. Kisi-kisi ini sangat penting dibuat untuk memberi arah terhadap hal-hal yang dipertanyakan dalam instrumen penelitian.Tujuan penyusunan kisi-kisi instrumen adalah merencanakan setepat mungkin ruang lingkup dan tekanan tes dan bagian-bagiannya, sehingga perumusan tersebut dapat menjadi petunjuk yang efektif bagi penyusunan penelitian tindakan kelas ini. 
Tabel 1. Instrumen Penilaian Kemauan Mengikuti Bimbingan dan Konseling

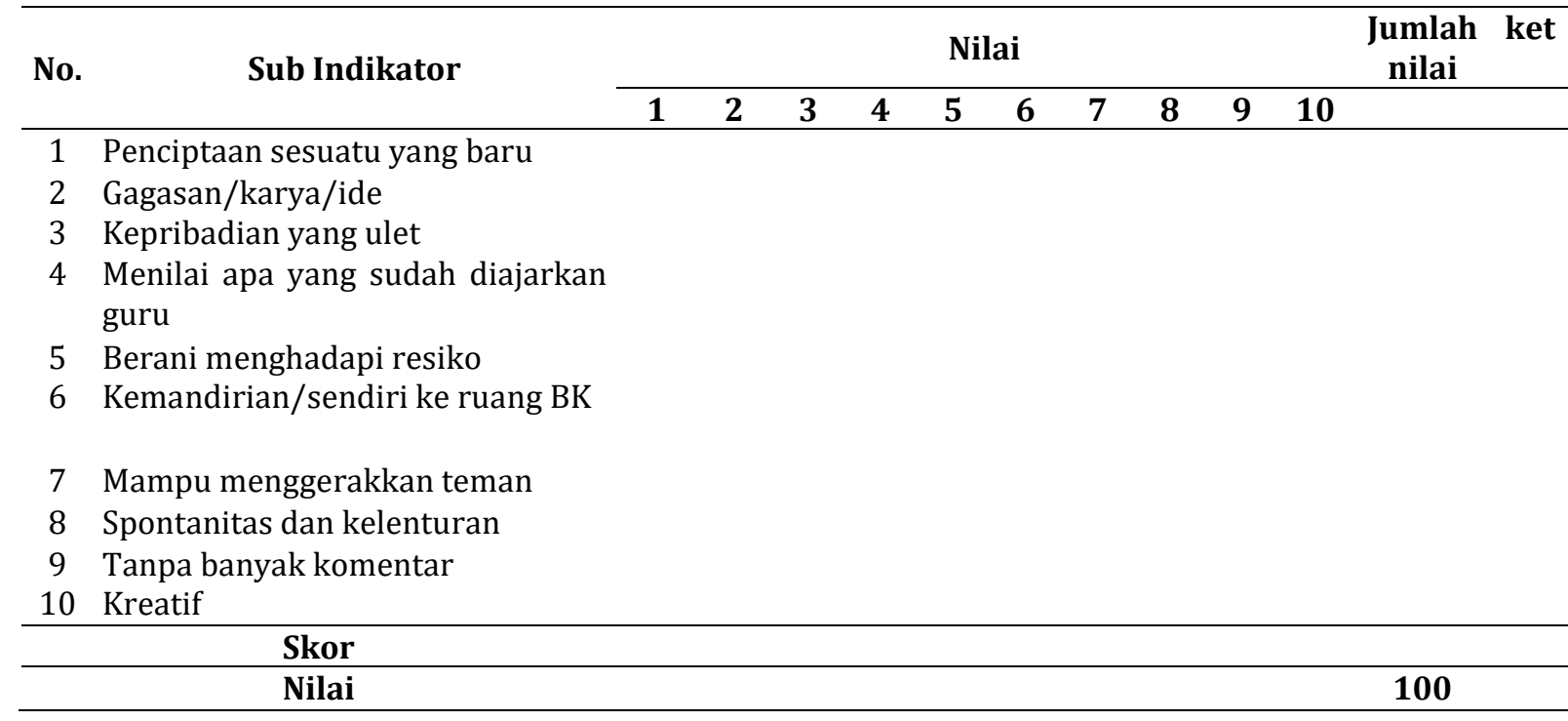

Dalam penelitian ini diusulkan tingkat keberhasilan meningkatnya komitmen peserta didik per siklus yaitu pada siklus I diusulkan mencapai nilai 70 dengan kriteria penilaian Cukup dan pada siklus II diharapkan mencapai nilai 80 dengan kriteria penilaian Baik atau Baik Sekali. Tingkat keberhasilan yang diusulkan di atas mengacu pada pendapat pakar pendidikan Indonesia dalam memberikan acuan penilaian.

$\begin{array}{lll}\text { Keterangan: } & \text { Kriteria penilaian: } \\ \mathrm{A}=\text { Amat Baik } & 0-54=\text { Sangat kurang } \\ \mathrm{B}=\text { Baik } & 55-64=\text { Kurang } \\ \mathrm{C}=\text { Cukup } & 65-79=\text { Cukup } \\ \mathrm{D}=\text { Tidak Baik } & 80-90=\text { Baik } \\ \mathrm{E}=\text { Amat tidak baik } & 91-100=\text { Baik sekali }\end{array}$

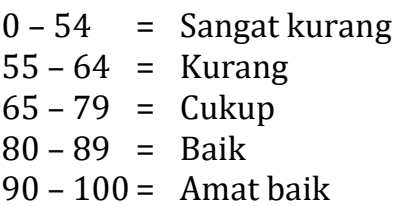

(Koyan, 2003: 56)

\section{ANALISIS DAN PEMBAHASAN}

1. Deskripsi Awal

Dari 41 peserta didik ada 6 orang yang kreativitas pada kualifikasi baik. ada 6 peserta didik yang memiliki kreativitas pada kualifikasi cukup, ada 15 peserta didik yang memiliki kreativitas pada kualifikasi kurang, sedangkan sebanyak 14 peserta didik tingkat kreativitas ada pada kualifikasi sangat kurang, yang berada pada rentang nilai 0 - 54. Kesimpulan refleksinya adalah kreativitas peserta didik kelas IXB semester I SMP Negeri 3 Denpasar tahun pelajaran 2018/2019 pada observsai awal masih kurang dengan nilai rata-rata 62,15. Paparan data di atas menggambar bahwa perlu dilakukan kegiatan bimbingan dan konseling untuk menyelesaikan masalah yang dihadapi ini.

2. Siklus I

a) Rencana Tindakan I

Kegiatan perencanaan tindakan siklus I meliputi : Menyusun perencanaan penelitian lengkap dengan rencana pelaksanaan layanan. Menentukan waktu pelaksanaan bimbingan dan konseling. Menyusun format pengecekan yang berhubungan dengan kreativitas. Memilih dan mengorganisaasikan materi, media, dan sumber belajar. Pada siklus pertama ini, peneliti mengorganisasikan materi pembelajaran dengan baik. Urutan penyampaiannya dari yang mudah ke yang sulit, cakupan materi cukup bermakna bagi peserta didik, menentukan alat bantu mengajar. Sedangkan dalam penentuan sumber belajar sudah disesuaikan dengan tujuan, materi pembelajaran dan tingkat perkembangan peserta didik. Merancang skenario layanan.

b) Pelaksanaan Tindakan I

Pada pelaksanaan penelitian siklus I peneliti melaksanakan layanan berdasarkan instrumen penilaian kreativitas sebagai berikut : Guru menciptakan sesuatu yang baru dalam kegiatan bimbingan. Guru menyampaikan gagasan/karya/ ide untuk meningkatkan kreatifitas peserta didik. 
Guru mengarahkan peserta didik untuk memiliki kepribadian yang ulet. Guru memperhatikan perkembangan peserta didik dengan menilai. Guru mengajarkan peserta didik untuk berani menghadapi resiko. Guru mengarhkan peserta didik untuk berani datang ke ruang BK. Peserta didik menggerakakan temannya untuk ikut bimbingan. Guru mengarahkan peserta didik untuk berpikir spontan. Guru mengarhkan peserta didik untuk tidak banyak berkomentar. Guru mengajak peserta didik untuk kreatif.

c) Observasi/Pengamatan

Data yang diperoleh dari kegiatan observasi yang dilakukan guru akan sangat berpengaruh terhadap kemajuan peneliti. Dari hasil observasi dapat disampaikan bahwa rata-rata tingkat kreativitas peserta didik adalah 71,43 dengan kualifikasi cukup.

d) Refleksi Siklus I

Analisis kuantitatifnya menggunakan data yang diperoleh adalah dalam bentuk angka sebagai berikut:

1) Rata-rata (mean) dihitung dengan : $\frac{\text { Jumlah wilai }}{\text { Jumlah siswa }}=\frac{2948}{41}=71,90$

2) Data Interval Kelas

Tabel 2. Data Interval Kelas Siklus I

\begin{tabular}{cccccc}
\hline $\begin{array}{c}\text { No } \\
\text { Urut }\end{array}$ & Interval & & $\begin{array}{c}\text { Nilai } \\
\text { Tengah }\end{array}$ & $\begin{array}{c}\text { Frekuensi } \\
\text { Absolut }\end{array}$ & $\begin{array}{c}\text { Frekuensi } \\
\text { Relatif }\end{array}$ \\
\hline 1 & 0 & 54 & 27,0 & 3 & 7,32 \\
2 & 55 & 64 & 59,5 & 12 & 29,27 \\
3 & 65 & 79 & 72,0 & 8 & 19,51 \\
4 & 80 & 90 & 85,0 & 17 & 41,46 \\
5 & 90 & 100 & 95,0 & 1 & 2,44 \\
\hline \multicolumn{7}{r}{} & Total & & 41 & 100,00 \\
\hline
\end{tabular}

3) Penyajian dalam bentuk histogram

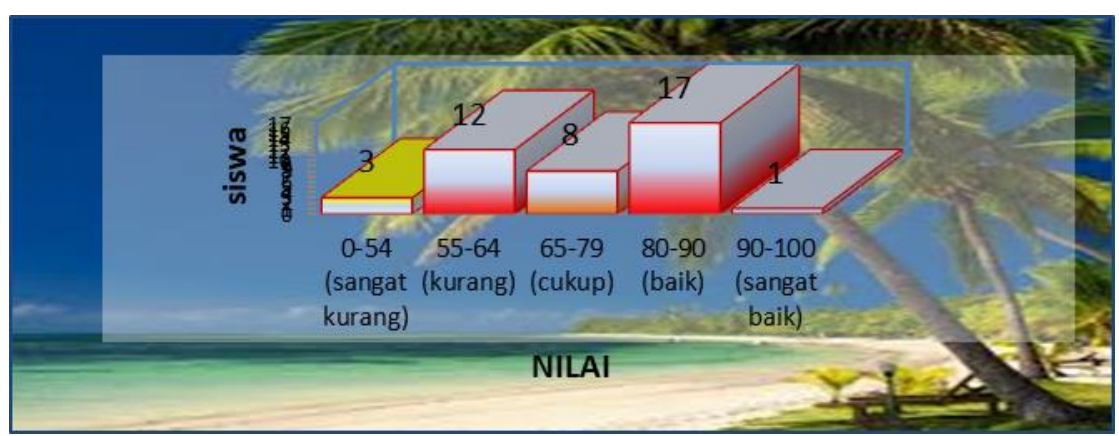

Gambar 2. Histogram Nilai Pengamatan Kreativitas Peserta didik Kelas IXB Semester I

Perolehan hasil dari pelaksanan tindakan pada siklus I dapat disampaikan, dari 41 peserta didik di Kelas IXB semester I SMP Negeri 3 Denpasar tahun pelajaran 2018/2019 yang diteliti 1 peserta didik memperoleh penilaian kualifikasi sangat baik, 17 peserta didik yang memperoleh penilaian kualifikasi baik dengan kriteria penilaian ada pada rentang nilai 80-90. Ada 8 peserta didik memperoleh penilaian kualifikasi cukup dengan kriteria penilaian ada pada rentang nilai 65-79 (Sutrisno Hadi, 2000: 17). Serta ada 12 peserta didik memperoleh penilaian kualifikasi kurang dan ada 3 peserta didik dikategori sangat kurang.

Pada pelaksanaan penelitian siklus I peneliti menemukan kekurangan-kekurangan seperti peserta didik masih susah dalam menyampaikan ide, peserta didik belum fokus dalam bimbingan dan konseling, peserta didik masih takut untuk datang keruang konseling. Sedangkan kelebihan yang ada adalah guru sudah mampu mengarahkan peserta didik untuk memiliki kepribadian yang ulet, guru sudah mampu mengajak peserta didik untuk kreatif. Kesimpulan refleksinya adalah masih banyak peserta didik yang kedisiplinannya cukup dan perlu pembinaan lanjutan. Oleh karenanya penelitian ini masih perlu untuk dilanjutkan kesiklus ke-II. 
3. Siklus II

a) Perencanaan

Melihat semua hasil yang didapat pada siklus I, baik refleksi data kualitatif maupun refleksi data kuantitatif, maka untuk perencanaan pelaksanaan penelitian di siklus II ini ada beberapa hal yang perlu dilakukan yaitu Menyusun perencanaan penelitian lengkap dengan rencana pelaksanaan layanan. Menentukan waktu pelaksanaan bimbingan dan konseling. Menyusun format observasi yang berhubungan dengan kreativitas. Memilih dan mengorganisaasikan materi, media, dan sumber layanan. Sedangkan dalam penentuan sumber belajar sudah disesuaikan dengan tujuan, materi layanan dan tingkat perkembangan peserta didik. Merancang skenario layanan.

b) Pelaksanaan Tindakan II

Pada pelaksanaan penelitian siklus II peneliti melaksanakan layanan berdasarkan instrumen penilaian kreativitas sebagai berikut : Guru menciptakan sesuatu yang baru dalam kegiatan bimbingan. Guru menyampaikan gagasan/karya/ ide untuk meningkatkan kreatifitas peserta didik. Guru mengarahkan peserta didik untuk memiliki kepribadian yang ulet. Guru memperhatikan perkembangan peserta didik dengan menilai. Guru mengajarkan peserta didik untuk berani menghadapi resiko. Guru mengarhkan peserta didik untuk berani datang ke ruang bimbingan konseling. Peserta didik menggerakakan temannya untuk ikut bimbingan. Guru mengarahkan peserta didik untuk berpikir spontan. Guru mengarhkan peserta didik untuk tidak banyak berkomentar. Guru mengajak peserta didik untuk kreatif.

c) Observasi/Penilaian

Pada tahap observasi guru mengamati, mencatat kreativitas peserta didik, kemauan peserta didik untuk ikut berpartisipasi dalam layanan, kontribusi diantara para peserta didik. Hasil observasi peserta didik siklus II akan dibahas pada refleksi II. Dari hasil observasi dapat disampaikan bahwa rata-rata tingkat kreativitas peserta didik adalah 81,20 dengan kualifikasi Baik.

d) Refleksi Siklus II

Analisis kuantitatifnya menggunakan data yang diperoleh adalah dalam bentuk angka sebagai berikut:

1) Rata-rata (mean) dihitung dengan : $\frac{\text { Jumlah nilai }}{\text { Jumlah siswa }}=\frac{3329}{41}=81,20$

2) Data Interval Kelas

Tabel 3. Data Interval Kelas Siklus II

\begin{tabular}{|c|c|c|c|c|c|c|}
\hline No Urut & \multicolumn{3}{|c|}{ Interval } & Nilai Tengah & Frekuensi Absolut & Frekuensi Relatif \\
\hline 1 & 0 & - & 54 & 27,0 & 0 & 0,00 \\
\hline 2 & 55 & - & 64 & 59,5 & 2 & 4,88 \\
\hline 3 & 65 & - & 79 & 72,0 & 6 & 14,63 \\
\hline 4 & 80 & - & 90 & 85,0 & 31 & 75,61 \\
\hline 5 & 90 & - & 100 & 95,0 & 2 & 4,88 \\
\hline \multicolumn{5}{|c|}{ Total } & 41 & 100,00 \\
\hline
\end{tabular}

3) Penyajian dalam Bentuk Histogram

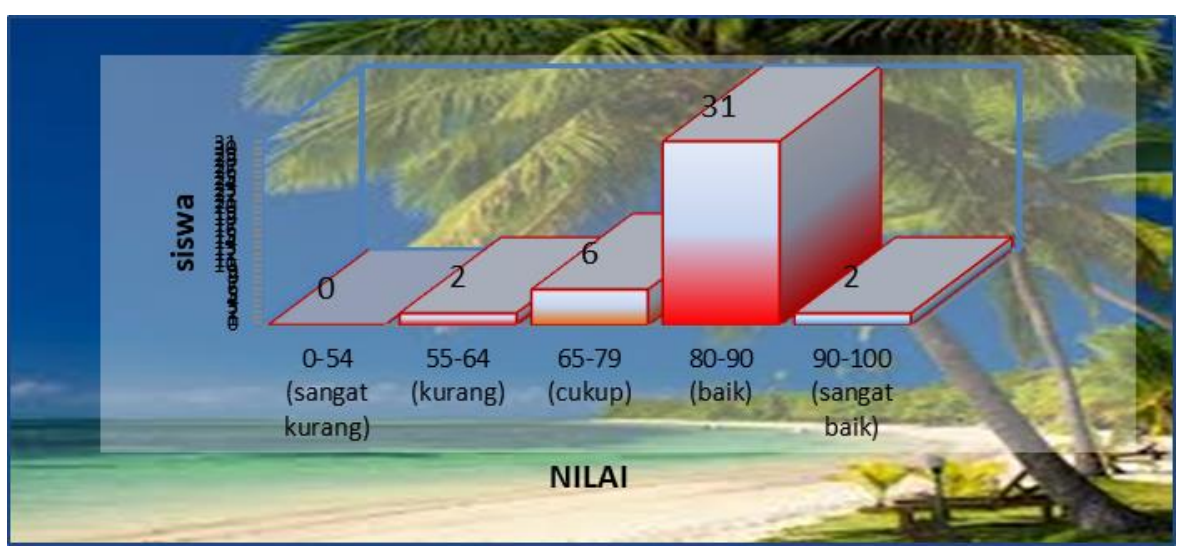

Gambar 3. Histogram Peningkatan Kreativitas Peserta didik Kelas IXB semester I 
Hasil analisis kreativitas peserta didik dalam bimbingan dan konseling siklus II adalah 2 orang peserta didik yang kreativitas pada kualifikasi sangat baik. Ada 31 orang peserta didik yang kreativitas pada kualifikasi baik. Ada 6 orang peserta didik yang kreativitas pada kualifikasi cukup. dimana kualifikasi cukup ini ada pada rentang nilai 65 - 79. Sedangkan masih ada 2 peserta didik tingkat kreativitas ada pada kualifikasi kurang. Hasil yang dapat disampaikan dari observasi siklus II adalah Kreativitas peserta didik kelas IXB semester I SMP Negeri 3 Denpasar tahun pelajaran 2018/2019 sudah pada kriteria Baik. Semua kekurangan yang terdapat pada siklus I sudah diperbaiki pada siklus II sehingga proses bimbingan sudah dapat berjalan dengan lancar dan kreativitas peserta didik dapat ditingkatkan.

Tabel 4. Rekapitulasi Hasil Penelitian dari Awal, Siklus I dan Siklus II

\begin{tabular}{cccccc}
\hline \multirow{2}{*}{ Variabel } & Awal & \multicolumn{2}{c}{ Tes Siklus I } & \multicolumn{2}{c}{ Tes Siklus II } \\
\cline { 2 - 6 } & $\begin{array}{c}\text { Rata-Rata } \\
\text { Perolehan Skor }\end{array}$ & $\begin{array}{c}\text { Rata-Rata } \\
\text { Perolehan } \\
\text { Skor }\end{array}$ & $\begin{array}{c}\text { Tingkat } \\
\text { Kenaikan }\end{array}$ & $\begin{array}{c}\text { Rata-Rata } \\
\text { Perolehan } \\
\text { Skor }\end{array}$ & $\begin{array}{c}\text { Tingkat } \\
\text { Kenaikan }\end{array}$ \\
\hline Kreativitas & 62,15 & 71,90 & 9,75 & 81,20 & 9,3 \\
\hline
\end{tabular}

Dari Tabel 4 diatas dapat disampaikan bahwa Kreativitas peserta didik mengikuti bimbingan dan konseling terus mengalami peningkatan dari perolehan rata-rata skor awal 62,15 naik menjadi 71,90 pada siklus I dan 91,20 pada siklus II.

Bimbingan merupakan salah satu bidang bimbingan yang sangat penting untuk diberikan kepada peserta didik karena dapat memberikan pemahaman kepada peserta didik tentang berbagai hal yang berkaitan dengan kegiatan belajar. Bimbingan membantu peserta didik mengembangkan diri, sikap dan kebiasaan belajar yang baik, menguasai pengetahuan dan keterampilan serta menyiapkannya melanjutkan pendidikan yang lebih tinggi. Bimbingan belajar merupakan bimbingan dalam hal menemukan cara belajar yang tepat dalam memilih program studi yang sesuai dan dalam mengatasi kesukaran-kesukaran yang timbul berkaitan dengan tuntutan-tuntutan belajar di suatu institusi pendidikan. Kondisi yang terjadi di SMP Negeri 3 Denpasar peneliti sebagai guru bimbingan konseling di kelas IXB Semester I SMP Negeri 3 Denpasar Tahun Pelajaran 2018/2019, menemukan bahwa peserta didik belum sepenuhnya memiliki kreativitas dalam belajar.

Dari hasil obeservasi di kelas Kelas IXB Semester I SMP Negeri 3 Denpasar Tahun Pelajaran 2018/2019 dapat disampaikan data diantaranya peserta didik sering merasa malas belajar, peserta didik tidak dapat menerapkan cara belajar yang baik, minat baca peserta didik rendah, peserta didik sulit mengerti isi buku pelajaran yang dibaca, sehingga mereka kurang memiliki usaha belajar, tidak memiliki kebiasaan belajar yang baik, dan masih terpaku dengan semua materi yang tertera di dalam buku tidak dengan mempelajari materi inti atau membuat ringkasan materi. Hal tersebut didukung dengan informasi yang diberikan oleh guru mata pelajaran bahwa ketika pelajaran peserta didik cenderung pasif atau berbicara dengan temannya dari pada bertanya atau menanggapi penjelasan dari guru.

Perolehan hasil dari pelaksanan tindakan pada siklus I dapat disampaikan, dari 41 peserta didik di kelas IXB semester I SMP Negeri 3 Denpasar tahun pelajaran 2018/2019 kategori yang dicapai setelah layanan adalah kategori cukup dengan rata-rata nilai 71,90. Pada pelaksanaan penelitian siklus I peneliti menemukan kekurangan-kekurangan seperti peserta didik masih susah dalam menyampaikan ide, peserta didik belum fokus dalam bimbingan dan konseling, peserta didik masih takut untuk datang keruang konseling. Sedangkan kelebihan yang ada adalah guru sudah mampu mengarahkan peserta didik untuk memiliki kepribadian yang ulet, guru sudah mampu mengajak peserta didik untuk kreatif. Kesimpulan refleksinya adalah masih banyak peserta didik yang kedisiplinannya cukup dan perlu pembinaan lanjutan. Oleh karenanya penelitian ini masih perlu untuk dilanjutkan kesiklus ke-II.

Hasil yang diperoleh dari kuisioner observasi di siklus II menunjukkan bahwa kemampuan peserta didik dalam mengikuti pelajaran sudah baik. Ini terbukti dari rata-rata nilai peserta didik mencapai 81,20 yang masuk kategori baik. Hasil ini menunjukkan bahwa kegiatan layanan bimbingan telah berhasil meningkatkan kreativitas peserta didik menempa ilmu sesuai harapan. Kegiatan bimbingan merupakan kegiatan yang cocok bagi peserta didik apabila guru menginginkan mereka memiliki kemampuan berkreasi, berargumentasi, mengeluarkan pendapat secara lugas, bertukar pikiran, berargumentasi, mengingat penggunaan metode ini adalah untuk memupuk kemampuan intelektual peserta didik, mendorong peserta didik untuk mampu menemukan sendiri, menempatkan peserta didik pada posisi sentral dan mengupayakan agar peserta didik tidak belajar dengan menghafal. 
Hasil yang dapat disampaikan dari observasi siklus II adalah kreativitas peserta didik kelas IXB semester I SMP Negeri 3 Denpasar tahun pelajaran 2018/2019 sudah pada kriteria Baik. Semua kekurangan yang terdapat pada siklus I sudah diperbaiki pada siklus II sehingga proses bimbingan sudah dapat berjalan dengan lancar dan kreativitas peserta didik dapat ditingkatkan sehingga penelitian tindakan ini tidak perlu dilanjutkan kembali karena sudah sesuai dengan tuntutan indikator yang diharapkan.

\section{KESIMPULAN}

Perolehan data awal yang rendah dan belum mencapai nilai kriteria ketuntasan yang harapan, membuat peneliti harus giat mengupayakan cara agar masalah pembelajaran yang ada dapat diperbaiki sehingga peningkatan kreativitas peserta didik dalam mengikuti bimbingan konseling dengan menerapkan contoh prilaku yang baik di kelas IXB semester I SMP Negeri 3 Denpasar Tahun Pelajaran 2018/2019 dapat ditingkatkan. Setelah melakukan perubahan dan perbaikan dari siklus I didapat peningkatan kreativitas yakni rata-rata kreativitas awal 62,15, pada siklus I naik menjadi 71,90 dan pada siklus II naik menjadi 81,20. Dari uraian diatas dapat disimpulkan bahwa kreativitas peserta didik dapat meningkat dalam mengikuti bimbingan konseling dengan menerapkan contoh prilaku yang baik di dikelas IXB Semester I SMP Negeri 3 Denpasar Tahun Pelajaran 2018/2019.

Berdasarkan kesimpulan dari hasil penelitian peneliti memberikan saran dalam rangka perbaikan proses pembelajaran serta meningkatkan prestasi belajar matematika, khususnya materi pencerminan. Saran-saran tersebut sebagai berikut : Bagi teman-teman guru pengajar bimbingan konseling disarankan mencoba menerapkan contoh-contoh prilaku baik untuk diterapkan di kelas yang dibimbing. Kepada Kepala SMP Negeri 3 Denpasar disarankan untuk untuk memberi penekanan agar guru mau melaksanakan pembelajaran dengan langkah-langkah model yang sudah diteliti. Penggunaan contohcontoh prilaku baik semestinya menjadi pilihan dari beberapa kegiatan bimbingan mengingat cara ini telah terbukti dapat meningkatkan kerjasama, berkreasi, bertindak aktif, bertukar informasi, mengeluarkan pendapat, bertanya, berdiskusi, berargumentasi dan lain-lain. Demi kesempurnaan penelitiaan ini, peneliti mengharapkan kritik, saran, masukan yang konstruktif, oleh karenanya disarankan pada peneliti lain untuk melakukan penelitian lanjutan guna menyempurnakan hasil-hasil yang telah diperoleh.

\section{DAFTAR PUSTAKA}

Afrianto, Irawan. 2011. Collaborative Learning System Sebuah Alternatif Konten C-Generation dan Flagship Detiknas. Majalah Ilmiah Unikom Vol.8, No. 1 Hal. 69-76. Tersedia Pada: https://jurnal.unikom.ac.id/jurnal/collaborative-learning-system.1e.

Boty, Middya, Ari Handoyo. 2018. Hubungan Kreativitas Dengan Hasil Belajar Siswa Kelas V Mata Pelajaran Bahasa Indonesia Di Mi Ma'had Islamy Palembang. JIP:Jurnal Ilmiah PGMI Volume 4, $\begin{array}{lllll}\text { Nomor } & 1 & \text { Hal. } & 41-55 . & \text { Tersedia }\end{array}$ http://jurnal.radenfatah.ac.id/index.php/jip/article/view/2265/1608.

Insano. 2004. Bimbingan dan Konseling. Jakarta : Ciputat Press.

Kamaluddin, H. 2011. Bimbingan dan Konseling Sekolah. Jurnal Pendidikan dan Kebudayaan, Vol. 17, Nomor 4, Hal. 447-454. Tersedia Pada: https://jurnaldikbud.kemdikbud.go.id/index.php/jpnk/article/view/40.

Munandar, Utami. 2009. Kreativitas \& Keberbakatan Strategi Mewujudkan Potensi Kreatif \& Bakat. Jakarta: PT Gramedia Pustaka Utama.

Munirah. 2015. Sistem Pendidikan di Indonesia: antara keinginan dan realita. Auladuna, Vol. 2 No. 2 Hal. 233-245. Tersedia Pada: http://journal.uin-alauddin.ac.id/index.php/auladuna/article/view/879.

Slameto. 2003. Belajar dan Faktor-faktor yang Mempengaruhinya. Jakarta: Rineka Cipta.

Suhaya. 2016. Pendidikan Seni Sebagai Penunjang Kreatifitas. Jurnal Pendidikan dan Kajian Seni Vol.1 No.1 Hal. $1-15 . \quad$ Tersedia http://jurnal.untirta.ac.id/index.php/JPKS/article/download/837/655. 
Tohirin, 2007, Bimbingan Konseling diSekolah dan Madrasah. Jakarta: Raja Grafindo Persada.

Yahya, Mohamad. 2013. Pengembangan Kreativitas Siswa dalam Proses Pembelajaran. Edu-Islamika Vol. 5. No. 01. Hal. 39-75. Tersedia Pada: http://ejournal.iainjember.ac.id/index.php/eduislamika/article/download/28/21. 